\title{
Changing trends in the indications of obstetric hysterectomies in teaching rural hospital
}

\author{
Arun P. Moray ${ }^{1}$, Urmila A. Moray ${ }^{2 *}$, Vaishali M. Patil ${ }^{1}$, Grishma A. Moray ${ }^{2}$
}

\begin{abstract}
${ }^{1}$ Department of Obstetrics and Gynecology, Shri. Bhausaheb Hire Government Medical College, Dhule, Maharashtra, India

${ }^{2}$ Department of Obstetrics and Gynecology, JMF’s ACPM Medical College, Dhule, Maharashtra, India
\end{abstract}

Received: 21 May 2018

Accepted: 26 June 2018

\author{
*Correspondence: \\ Dr. Urmila A. Moray, \\ E-mail: arunmoray@gmail.com
}

Copyright: () the author(s), publisher and licensee Medip Academy. This is an open-access article distributed under the terms of the Creative Commons Attribution Non-Commercial License, which permits unrestricted non-commercial use, distribution, and reproduction in any medium, provided the original work is properly cited.

\begin{abstract}
Background: Obstetric hysterectomy $(\mathrm{OH})$ still remains lifesaving procedure. $\mathrm{OH}$ still poses a major obstetrical morbidity in the developing world due to lack of human, infrastructural and monetary resources. Irrespective of attempts like good antenatal care and delivery planning in modern obstetrics to prevent major obstetric complications; unfortunately, $\mathrm{OH}$ needs to be performed at times even today. The aim of present study was to determine the changes in the indications of obstetric hysterectomy.

Methods: A retrospective review based on hospital data of all the patients' records subjected to OH from January 1994 to September 2001 (Gr. A) and from January 2006 to December 2015 (Gr. B) was done and analyzed for incidence and changing trends in the indications.

Results: The incidence of OH during two periods from January 1994 to September 2001 (Group A) and from January 2006 to December 2015 (Group B) in the Department of Obstetrics and Gynecology at Shri. Bhausaheb Hire Govt. Medical College, Dhule was 3.27/1000 and 0.97/1000 deliveries. Incidence is reduced by more than three folds. In both groups maximum patients were below $30 \mathrm{yrs}$ of age and multipara. The commonest indications for $\mathrm{OH}$ in both groups were uterine rupture, uncontrolled Atonic PPH and placental causes. The incidence of uterine rupture as a cause for $\mathrm{OH}$ was reduced from $78.16 \%$ to $43.24 \%$, while that of Atonic PPH has increased from $16.09 \%$ to $28.37 \%$ and placental causes has increased from $4.59 \%$ to $9.45 \%$. Among the risk factors for $\mathrm{OH}$, the incidence of prolonged or obstructed labour has reduced from $66.66 \%$ to $21.62 \%$ and that of malpresentations has reduced from 27.58 to $5.4 \%$.

Conclusions: There is definite reduction in the incidence of $\mathrm{OH}$, frequency of uterine rupture, obstructed labor and malpresentations in Gr. B due to timely referral, improved infrastructure and transportation facilities.
\end{abstract}

Keywords: Atonic PPH, Obstetric hysterectomy, Uterine rupture

\section{INTRODUCTION}

Obstetric hysterectomy $(\mathrm{OH})$ means surgical removal of uterus during ante partum, intra partum or postpartum period due to various obstetric complications. $\mathrm{OH}$, still poses a major obstetrical morbidity in the developing world due to lack of human, infrastructural and monetary resources. Irrespective of attempts like good antenatal care and delivery planning in modern obstetrics to prevent major obstetric complications; unfortunately, $\mathrm{OH}$ needs to be performed at times even today.

$\mathrm{OH}$ was developed as a heroic operation of necessity in an attempt to reduce the exceptional maternal mortality 
rate of caesarean section which was around $100 \%$ in the beginning. The first $\mathrm{OH}$ was performed by Horatio R. Storer in 1868 for obstruction in birth canal by a uterine tumor, but patient died on the third post-operative day. ${ }^{1}$ Eduardo Porro was the first to perform $\mathrm{OH}$ on a patient who survived it. Up to $1922,25 \%$ of caesarean deliveries were performed as Porro's caesarean hysterectomies.

Patients requiring $\mathrm{OH}$ represent large proportion of critical patients coming to obstetrics units. Its management involves coordinated team work, anesthetic skills, promptness, round the clock blood transfusion services, good operative skills and post-operative critical management. The study of these cases gives opportunity to improve the above aspects as well as to extend the necessary preventive services to the needy. Majority of indications for $\mathrm{OH}$ are Atonic postpartum hemorrhage, ruptured uterus and placental disorders.

In the present study the patients undergoing $\mathrm{OH}$ at Shri. Bhausaheb Hire Govt. Medical College and Hospital, Dhule in two different period intervals were analysed to find out the changing trends in incidence and the indications.

\section{METHODS}

This study was conducted in the Department of Obstetrics and Gynecology, Shri. Bhausaheb Hire Government Medical College and Hospital, Dhule, Maharashtra, India. This hospital caters mainly for the patients from tribal and rural areas. Study design was retrospective in nature where data was collected from labor ward and operation theatre records. The surgical removal of the uterus at the time of planned or unplanned caesarean delivery or at exploratory laparotomy or in the immediate postpartum period was considered as obstetric hysterectomy $(\mathrm{OH})$. All the patients' records subjected to $\mathrm{OH}$ from January 1994 to September 2001 (Group A) and from January 2006 to December 2015 (Group B) were collected and analyzed. The data collected and analyzed was total no. of deliveries, number of caesarean sections, no. of $\mathrm{OH}$, age of mother, parity, indication for $\mathrm{OH}$ and associated co morbidities during above two period intervals. Study was approved by Institutional ethical committee.

\section{Statistical analysis}

Quantitative analysis of the data was done. Descriptive analysis which includes frequency distribution showing number and percentages were generated for each identified variable. Statistical tests like Chi Square and probability were applied when indicated and the occurrences were compared.

\section{RESULTS}

Statistically significant decline in the rate of obstetrical hysterectomies in recent past (2006-2015 i.e. Gr. B) as compared with the previous years (1994-2001 i.e. Gr. A) cumulatively and among women delivered vaginally. However, $\mathrm{OH}$ among women undergone caesarean deliveries was not significantly reduced. Higher proportion of $\mathrm{OH}$ among women more than 30 years of age was noted. The difference in the proportion was statistically non-significant. High proportion of $\mathrm{OH}$ among multiparous women was observed. The difference in the proportion was statistically significant.

Table 1: Baseline information of $\mathrm{OH}$ conducted during the study period.

\begin{tabular}{|c|c|c|c|}
\hline Parameter & $\begin{array}{l}\text { Jan } 1994 \text { to Sept } \\
\text { 2001(Gr. A) }\end{array}$ & $\begin{array}{l}\text { Jan } 2006 \text { to Dec } 2015 \\
\text { (Gr. B) }\end{array}$ & Significance \\
\hline Total no. of deliveries & 26614 & 76375 & \multirow{3}{*}{$\begin{array}{l}\text { Chi Sq }{ }^{*}=65.43 \\
\mathrm{p}<0.0001\end{array}$} \\
\hline Total no of obstetrical hysterectomies & 87 & 74 & \\
\hline Incidence - per thousand deliveries & $3.27 / 1000$ & $0.97 / 1000$ & \\
\hline Total no. of vaginal deliveries & 24065 & 64906 & \multirow{3}{*}{$\begin{array}{l}\text { Chi Sq }{ }^{*}=8.22 \\
\mathrm{p}=0.0041\end{array}$} \\
\hline Total no. of $\mathrm{OH}$ in vaginally delivered patients & 19 & 20 & \\
\hline $\begin{array}{l}\text { Incidence of } \mathrm{OH} \text { among vaginal deliveries- per } \\
\text { thousand deliveries }\end{array}$ & $0.79 / 1000$ & $0.31 / 1000$ & \\
\hline Total no. of caesarean deliveries & 2549 & 11469 & \multirow{3}{*}{$\begin{array}{l}\text { Chi Sq }{ }^{*}=2.85 \\
\mathrm{p}=0.091\end{array}$} \\
\hline Total caesarean hysterectomies & 10 & 22 & \\
\hline $\begin{array}{l}\text { Incidence of } \mathrm{OH} \text { among caesarean deliveries- per } \\
\text { thousand caesareans }\end{array}$ & $3.9 / 1000$ & $1.918 / 1000$ & \\
\hline
\end{tabular}

As uterine rupture was indication for $\mathrm{OH}$ in $2 / 3^{\text {rd }}$ cases of Gr. A, prolonged or obstructed labor and malpresentations were common associated risk factors than Gr. B. Over the years it was observed that uterine rupture as the cause for $\mathrm{OH}$ was reduced significantly in the recent past, while miscellaneous causes such as broad ligament hematoma, sepsis and ectopic pregnancy etc were increased during recent years. It was noted that $\mathrm{OH}$ was significantly reduced among prolonged or obstructed labor and fetal malpresentations cases. Most cases among malpresentations were neglected cases of transverse lie with hand prolapsed. There is no significant change in preeclampsia as a risk factor. 
Table 2: Age wise distribution in two groups.

\begin{tabular}{|c|c|c|c|}
\hline Parameter & $\begin{array}{l}\text { Jan } 1994 \\
\text { to Sept } \\
2001 \text { (Gr. } \\
\text { A), N=87 }\end{array}$ & $\begin{array}{l}\text { Jan } 2006 \\
\text { to Dec } \\
2015 \text { (Gr. } \\
\text { B), N=74 }\end{array}$ & Significance \\
\hline \multicolumn{4}{|c|}{ Age wise distribution } \\
\hline$<30$ yrs & $53(60.91 \%)$ & $47(63.51 \%)$ & \multirow{2}{*}{$\begin{array}{l}\text { Chi Sq }=0.03 \\
p=0.862\end{array}$} \\
\hline$>30 \mathrm{yrs}$ & $34(39.08)$ & $27(36.49 \%)$ & \\
\hline
\end{tabular}

Table 3: Parity wise distribution in two groups.

\begin{tabular}{|c|c|c|c|}
\hline Parameter & $\begin{array}{l}\text { Jan } 1994 \\
\text { to Sept } \\
2001(\mathrm{Gr} \text {. } \\
\text { A), N=87 }\end{array}$ & $\begin{array}{l}\text { Jan } 2006 \\
\text { to Dec } \\
2015(\mathrm{Gr} \text {. } \\
\text { B), N=74 }\end{array}$ & Significance \\
\hline \multicolumn{4}{|c|}{ Parity wise distribution } \\
\hline Primipara & $3(3.44 \%)$ & $12(83.78 \%)$ & \multirow{2}{*}{$\begin{array}{l}\text { Chi } \mathrm{Sq}=6.28 \\
\mathrm{p}=0.012\end{array}$} \\
\hline Multipara & $84(96.56 \%)$ & $62(16.22 \%)$ & \\
\hline
\end{tabular}

Table 4: Indications for $\mathrm{OH}$ in two groups.

\begin{tabular}{|c|c|c|c|}
\hline Indications for $\mathrm{OH}$ & $\begin{array}{l}\text { Jan } 1994 \text { to Sept } 2001 \\
\text { (Gr.A), N=87 }\end{array}$ & $\begin{array}{l}\text { Jan } 2006 \text { to Dec } \\
2015 \\
(G r . B) N=74\end{array}$ & Significance \\
\hline Uterine rupture & $68(78.16 \%)$ & $32(43.24 \%)$ & Chi $\mathrm{Sq}=19.26 ; \mathrm{p}=0.0001$ \\
\hline Uncontrolled Atonic PPH & $14(16.09 \%)$ & $21(28.37 \%)$ & Chi $\mathrm{Sq}=2.86 ; \mathrm{p}=0.09$ \\
\hline Placental causes & $4(4.59 \%)$ & $4(4.59 \%)$ & \multirow{4}{*}{$\begin{array}{l}\text { Chi Sq=2.43, } \\
p=0.12\end{array}$} \\
\hline Placenta previa & $2(2.29 \%)$ & $3(4.05 \%)$ & \\
\hline Abruption & $1(1.14 \%)$ & $2(2.7 \%)$ & \\
\hline Morbidly adherent placenta & $1(1.14 \%)$ & $2(2.7 \%)$ & \\
\hline $\begin{array}{l}\text { Perforation of uterus during voluntary } \\
\text { termination of pregnancy }\end{array}$ & 0 & $4(5.4 \%)$ & Cannot apply TOS \\
\hline Broad ligament hematoma & $1(1.14 \%)$ & $3(4.05 \%)$ & \multirow{6}{*}{$\begin{array}{l}\text { Chi } \mathrm{Sq}=5.76 \\
\mathrm{p}=0.016\end{array}$} \\
\hline Sepsis & $1(1.14 \%)$ & $2(2.7 \%)$ & \\
\hline Ectopic pregnancy & 0 & $2(2.7 \%)$ & \\
\hline Vesicular mole & 0 & $1(1.35 \%)$ & \\
\hline Uterine inversion & 0 & $1(1.35 \%)$ & \\
\hline Cervical fibroid & 0 & $1(1.35 \%)$ & \\
\hline
\end{tabular}

Table 5: Risk factors associated in both groups.

\begin{tabular}{|c|c|c|c|}
\hline Risk factor & $\begin{array}{l}\text { Jan } 1994 \text { to Sept } 2001 \\
\text { (Group A), N=87 }\end{array}$ & $\begin{array}{l}\text { Jan } 2006 \text { to Dec } \\
2015 \\
\text { (Group B) N=74 }\end{array}$ & Significance \\
\hline Multiparity & $84(96.56 \%)$ & $62(83.78 \%)$ & Chi $\mathrm{Sq}=6.28 ; \mathrm{p}=0.012$ \\
\hline Advanced maternal age $(>30)$ & $34(39.08 \%)$ & $27(36.48 \%)$ & Chi Sq=0.03; $p=0.86$ \\
\hline Prolonged or obstructed labor & $58(66.66 \%)$ & $16(21.62 \%)$ & Chi Sq=30.88; $p<0.0001$ \\
\hline Previous scar on uterus & $6(6.89 \%)$ & $22(29.72 \%)$ & Chi Sq=12.97; $p=0.0003$ \\
\hline Fetal malpresentations & $24(27.58 \%)$ & $4(5.4 \%)$ & \multirow{4}{*}{ Chi $\mathrm{Sq}=12.19 ; \mathrm{p}=0.0005$} \\
\hline $\begin{array}{l}\text { Transverse lie with hand } \\
\text { prolapse }\end{array}$ & $22(25.28 \%)$ & $3(4.05 \%)$ & \\
\hline Face presentation & $1(1.14 \%)$ & $1(1.35 \%)$ & \\
\hline Breech presentation & $1(1.14 \%)$ & 0 & \\
\hline Preeclampsia & $15(17.24 \%)$ & $13(17.56 \%)$ & Chi Sq=0.02; $p=0.89$ \\
\hline Multiple pregnancy & $2(2.29 \%)$ & $1(1.36 \%)$ & $\begin{array}{l}\text { TOS cannot be applied as } \\
\text { outcome was very scarce. }\end{array}$ \\
\hline
\end{tabular}

\section{DISCUSSION}

From Table 6, it is obvious that the incidence of $\mathrm{OH}$ has reduced by more than three folds in $\mathrm{Gr}$. B and this is statistically significant $(\mathrm{p}<0.0001)$.

Similar statistically significant decline in incidence of $\mathrm{OH}$ is seen in patients delivered vaginally.
The incidence of $\mathrm{OH}$ at our institute is comparable with that of various series worldwide with definitive decline in the incidence over the years.

This reduction in incidence is mainly due to reduction in frequency of number of uterine rupture cases from $78.16 \%$ in Gr. A to $43.24 \%$ in Gr. B as shown in Table 7. 
Table 6: Incidence of $\mathrm{OH}$ in various series worldwide.

\begin{tabular}{|c|c|c|c|}
\hline Series & Incidence per 1000 & Series & Incidence per 1000 \\
\hline Zelop et $\mathrm{al}^{2}$ & 1.55 & Vazquez et $\mathrm{al}^{6}$ & 8 \\
\hline Kant et $\mathrm{al}^{3}$ & 2.6 & Siddiq et $\mathrm{al}^{7}$ & 5.6 \\
\hline Gupta et $\mathrm{al}^{4}$ & 2.6 & Sharma et al ${ }^{8}$ & 5.4 \\
\hline Kanwar et al ${ }^{5}$ & 3.2 & Kanhere et $\mathrm{al}^{9}$ & 2.8 \\
\hline $\begin{array}{l}\text { Present series Gr. A, Jan 94- } \\
\text { Sept } 2001\end{array}$ & 3.27 & $\begin{array}{l}\text { Present series Gr. B, Jan } 2006 \text { to } \\
\text { Dec } 2015\end{array}$ & 0.97 \\
\hline
\end{tabular}

Table 7: Indication wise comparison of various series of $\mathrm{OH}$.

\begin{tabular}{|c|c|c|c|c|c|c|c|c|c|c|c|c|}
\hline \multirow{2}{*}{ Indication } & \multicolumn{2}{|c|}{ Clark et $\mathbf{a l}^{10}$} & \multicolumn{2}{|c|}{ Stanco et al ${ }^{11}$} & \multicolumn{2}{|c|}{ Zelop et $\mathbf{a l}^{2}$} & \multicolumn{2}{|c|}{$\begin{array}{l}\text { Parmar et } \\
\mathrm{al}^{12}\end{array}$} & \multicolumn{2}{|c|}{$\begin{array}{l}\text { Present series } \\
\text { Gr. A }\end{array}$} & \multicolumn{2}{|c|}{$\begin{array}{l}\text { Present series } \\
\text { Gr.B }\end{array}$} \\
\hline & $\mathrm{N}=70$ & $\%$ & $\mathrm{~N}=123$ & $\%$ & $\mathbf{N}=117$ & $\%$ & $\mathbf{N}=\mathbf{3 7}$ & $\%$ & $\mathrm{~N}=87$ & $\%$ & $\mathrm{~N}=74$ & $\%$ \\
\hline Placenta accreta & 21 & 30 & 55 & 45 & 75 & 64 & 3 & - & 2 & 2.29 & 3 & 4.05 \\
\hline Uterine Atony & 30 & 43 & 25 & 20 & 25 & 21 & 3 & - & 14 & 16.09 & 21 & 28.37 \\
\hline $\begin{array}{l}\text { Bleeding / Ut. } \\
\text { perforation/ } \\
\text { others }\end{array}$ & - & - & 19 & 16 & - & 3 & 12 & - & 0 & - & 4 & - \\
\hline Uterine rupture & 9 & 13 & 14 & 11 & 10 & 9 & 19 & - & 68 & 78.16 & 32 & 43.24 \\
\hline $\begin{array}{l}\text { Fibroids with } \\
\text { bleeding }\end{array}$ & 3 & 4 & 3 & 2 & 2 & 2 & - & - & - & - & 1 & 1.35 \\
\hline Uterine infection & - & - & 1 & 1 & 3 & 3 & - & - & 1 & 1.14 & 2 & 2.7 \\
\hline $\begin{array}{l}\text { Uterine Scar } \\
\text { rupture }\end{array}$ & 7 & 10 & - & - & 2 & 2 & - & - & 6 & 6.89 & 22 & 29.72 \\
\hline
\end{tabular}

From Table 4 it is obvious that the no. of cases of prolonged or obstructed labour is reduced from $66.66 \%$ to $28.62 \%$ in Gr. B. Similarly, number of cases of fetal malpresentations as risk factor for obstructed or prolonged labour leading to uterine rupture have significantly reduced from $27.58 \%$ in Gr. A to $5.4 \%$ in Gr. B ( $p=0.0005)$. This all suggests improvement in detection of high risk cases at peripheral primary health care centers and timely referral avoiding the delay. The lack of transport facilities or delay in availing them used to be main reason for delay in receiving timely management at tertiary care center. Due to provision of on call ambulance services under national rural health mission, transportation has become easy and hassle free. This is main reason for reduction in delayed transfer and indirectly reducing no. of cases of uterine rupture, prolonged or obstructed labor. Similarly, government initiatives like training of medical officers and auxiliary nurse midwives through basic essential obstetric care (BEmOC) and skilled attendant at birth (SAB) has helped in identifying high risk cases ante partum and intra partum with timely referral.

Improvement in the infrastructure at tertiary care hospital with development of High Dependency Units, well equipped operation theatres, improved blood bank facilities with availability of blood components and availability of higher antibiotics has improved the standards of the critical obstetric care. In Gr. B, the frequency of uncontrolled PPH, placental causes and previous scar on uterus has increased as compared to Gr.
A. Rupture uterus is still the leading indication for $\mathrm{OH}$ in Gr. B. This suggests increased incidence of caesarean deliveries over the period leading to more cases of abnormal placentation and scar rupture during VBAC. Even though there is reduction in the incidence of $\mathrm{OH}$ in Gr. B, it is still more than that of developed countries. Hence there is further need to improve infrastructure and provide qualified manpower in peripheral hospitals so that definitive management of high risk cases is made available at First Referral Units rather than referring them to tertiary health care facilities.

\section{CONCLUSION}

Over the years the incidence of $\mathrm{OH}$ has statistically reduced with significant reduction in incidence of uterine rupture and prolonged or obstructed labor. The incidence of rupture uterus has increased in scarred uterus, while reduced in vaginal deliveries. There is no reduction in preeclampsia as risk factor. There is increase in the incidence of uncontrolled $\mathrm{PPH}$ and placental causes leading to $\mathrm{OH}$. $\mathrm{OH}$ is a lifesaving procedure but decision should be prompt and performed by an experienced surgeon. Every obstetrician should be trained to perform this procedure.

\section{ACKNOWLEDGMENTS}

Authors would like to thank Dr. Satishkumar S. Gupta, Dr. Vijay Bhagat and Labour room - OT sister in charge, for their support during study. 
Funding: No funding sources

Conflict of interest: None declared

Ethical approval: The study was approved by the Institutional Ethics Committee

\section{REFERENCES}

1. Larry C, Gilstrap III F, Cunningham G. Van dorten JP. Obstetric Hysterectomy. operative obstetrics, $2^{\text {nd }}$ edition. New York: Mc Graw Hill. 1995:275-91.

2. Zelop CM, Harlow BL, Frigoletto FD, Safon LE, Saltzman DH. Emergency obstetrical hysterectomy. Am J Obstet Gynecol. 1993;168(5):1443-8.

3. Kant A, Wadhwani K. Emergency obstetric hysterectomy: J Obstet Gynecol India. 2005;55:32-4.

4. Gupta S, Dave A. Bandi G et al. Obstetric hysterectomy in modern day obstetrics. J Obstet Gynecol India. 2001;51:91-3.

5. Kanwar M, Sood PL, Gupta KB, et al. Emergency hysterectomy in obstetrics. J Obstet Gynecol India. 2003;53:350-2.

6. Vázquez JA, Rivera GV, Hernández Higareda $\mathrm{S}$, Páez FG, Vega CC, Segura AP. Obstetric hysterectomy. Incidence, indications and complications. Gynecol Obstetrics Mexico. 2008;76(03):156-60.

7. Siddiq N, Ghazi AS, Jabbar SH, Ali TE. Emergency Obstetrical hysterectomy (EOH): A life saving procedure in obstetrics. Pak J Surg. 2007;23:217-9.
8. Sharma R, Shaheen JP. Peripartum Hysterectomy: A review of 70 cases. J South Asian Federat Obstetr Gynecol. 2009;1(2):19-21.

9. Kanhere A, Sapkal R. Obstetric hysterectomy: aretrospective study at a tertiary care centre. Int $\mathbf{J}$ Reprod Contracept Obstetr Gynecol. 2016;2(4):5625.

10. Clark SL, Yeh SY, Phelan JP, Bruce S, Paul RH. Emergency hysterectomy for obstetric hemorrhage. Obstetr Gynecol. 1984;64(3):376-80.

11. Stanco LM, Schrimmer DB, Paul RH, Mishell DR, Jr. Emergency Obstetrical Hysterectomy and associated risk factors. Am J Obstetr Gynecol. 1993;168(3):870-83.

12. Parmar KD, Goswami D, Kavita M, and Jain M. Obstetric Hysterectomy: Retrospective analytical study at PDU Medical College, Rajkot Parmar Prakash. Int J Biomed Adv Res. 2014;05(05):253-4.

Cite this article as: Moray AP, Moray UA, Patil VM, Moray GA. Changing trends in the indications of obstetric hysterectomies in teaching rural hospital. Int J Reprod Contracept Obstet Gynecol 2018;7:3184-8. 